\section{Døvhet til besvær}

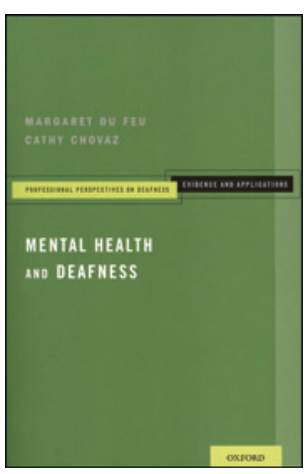

Margaret du Feu, Cathy Chovaz Mental health and deafness

296 s, tab. Oxford: Oxford University Press, 2014. Pris: GBP 26

ISBN 978-0-19-986075-3

Dette er en lettfattet introduksjon til de døves verden. Boken passer godt for leger, sykepleiere og annet helsepersonell som av og til jobber med døve pasienter, men også for de som jobber mye med døve.

Den er delt inn i 21 korte kapitler og handler mest om de som er født døve, eller som er blitt døve i ung alder. Boken omtaler kortfattet temaer om blant annet barn, ungdom, eldre, relasjon til foreldre, utdanning, utfordringer i samfunnet, døvhet i historisk perspektiv, rettsmedisinske utfordringer, klinisk vurdering av døve, behandling av døve, schizofreni, bipolaritet og depresjon. Døvblitte og døvblinde nevnes kort $\mathrm{i}$ egne kapitler. Teksten er enkel og lettlest, med hovedfokus på selve døvheten.

Viktigheten av språkutvikling, eller mangel på sådan, kommunikasjon og kommunikasjonsform nevnes spesielt. Mestrer egentlig pasienten skriftlig kommunikasjon? Tror du at døve kan forstå det du sier, ved å lese på leppene? Hvordan skal man bruke tolk, og hva er tolkens rolle? Det er lett å trå feil.

Det unike med boken er at alle kapitlene har en rekke korte, kliniske eksempler som illustrerer hvor lett det oppstår feil og misforståelser i møtet mellom hørende og døve. Og tro meg; det oppstår mange feil og misforståelser når denne pasientgruppen har behov for helsehjelp. Både underbehandling og overbehandling er vanlig, uten at de gode hjelperne skjønner hvor galt av sted det bærer.

Denne boken har vi ventet på, og den anbefales. Det hadde riktignok vært enda bedre med en norsk bok som refererer til nordiske forhold, men alle de triste og/eller tragiske kliniske eksemplene som det refereres til, kunne like gjerne vært fra Norge.

\section{Maja Husa Jakobsen}

Lege for døve, Legene på Sinsen

Oslo

\section{Mange utfordringer $\mathrm{i}$ behandling av Crohns sykdom og ulcerøs kolitt}

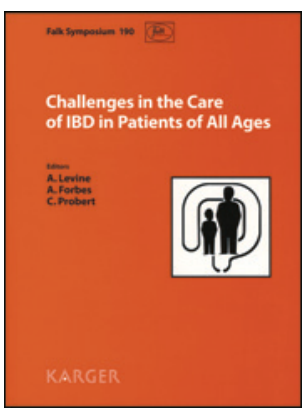

Arie Levine, Alastair Forbes,

Chris Probert, red.

Challenges in the care of IBD in patients

of all ages

Falk Symposium 190. 174 s, tab, ill. Basel:

Karger, 2014. Pris CHF 82

ISBN 978-3-318-02662-7

Boken henvender seg spesielt til dem som er litt mer enn normalt opptatt av og behandler pasienter med ulcerøs kolitt og Crohns sykdom (til sammen kalt inflammatorisk tarmsykdom (IBD, inflammatory bowel disease). Temaene favner bredt og omhandler så vel barn og unge som voksne. Utgivelsen er en samling oversiktsartikler skrevet av eksperter innenfor fagfeltet og presentert ved møtet arrangert av Falk Foundation i London i 2013. Forfatternes hensikt er å oppdatere leseren ved primært å gi en forenklet oversikt over et fagfelt i voldsom utvikling og endring - sekundært en forståelse av nye behandlingstilnærminger.

Kapitlene er organisert tematisk, og hver av forfatterne har fått problemstillinger å besvare: 1) Er det mulig å endre sykdomsforløpet ved måten man følger opp og kontrollerer? 2) Kan vi endre og derved bedre forløpet av Crohns sykdom med nye behandlingsprinsipper, og hvor/når bør i så fall dette skje? 3) Er det nye måter å tenke om sykdomsmekanismer og behandlingsprinsipper på? 4) Hvilken behandlingsstrategi tenker man seg i de vanskelige tilfellene av Crohns sykdom? 5) Bør behandlingsmålet endres fra å dempe inflammasjon til å fjerne bakterier? Bør vedlikeholdsbehandling intensiveres, og kan den optimaliseres mer? 6) Hvordan kan vi takle problemer vi stadig vil se pga. sykdommens natur, som residiverende og behandlingsrefraktære ulcerøse kolitter, intraktable pouchitter og primær skleroserende kolangitt? 7) Nye fremskritt i forskningen 2013. 8) Hvilken langtidsrisiko for kreftutvikling innebærer det når vi starter tidlig immunhemmende behandling hos barn og unge? 9) Hvilke nye ikke-invasive metoder (bildemessige) og undersøkelser av biologisk materiale (urin og avføring) kan endre fremtidens diagnostisering av inflammatorisk tarmsykdom? Behandling med cannabis ved aktiv Crohns sykdom. Behandlingsmuligheter for å bedre tarmbarrierens lekkasje (som i dag anses å være en sentral årsak til sykdomsutvikling) ved å modifisere mucus, glykokalyks, «tight junctions» og defensiner. Hvert kapittel følges av sentrale referanser i antall fra 30 til 70.

Oppsummert er boken en oppdatert gjennomgang av vanskelige problemstillinger som de som behandler pasienter med Crohns sykdom og ulcerøs kolitt, ser i en klinisk hverdag. Den vil også være til nytte for dem som ønsker å bli oppdatert innenfor spesifikke temaer. Siden viktige områder er utelatt, er den derimot ikke en fyllestgjørende oversikt av temaet inflammatorisk tarmsykdom.

Bjørn Moum

Overlege, Avdeling for fordøyelsessykdommer

Oslo universitetssykehus 